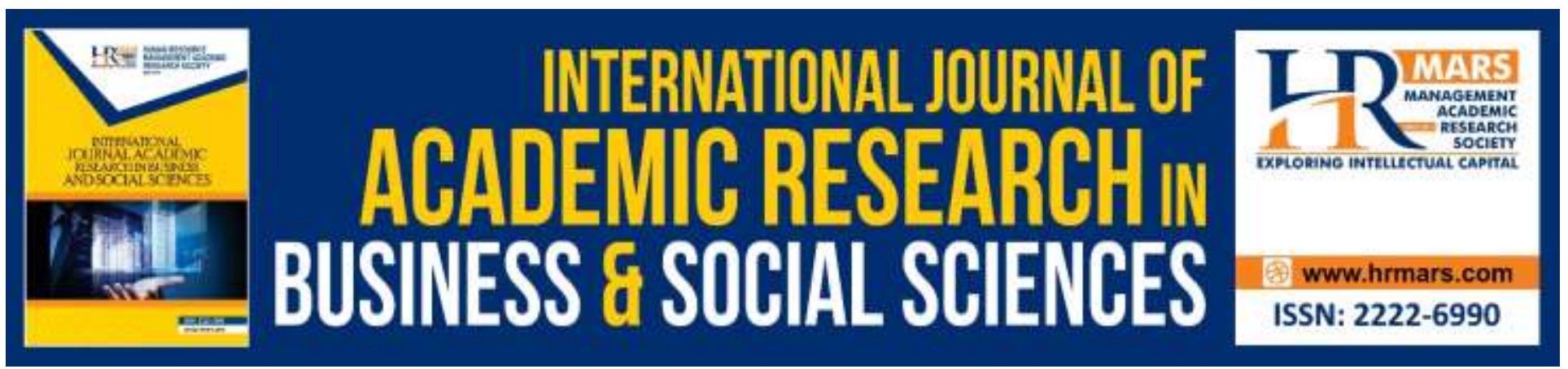

\title{
Humankind as Actors of Development According to the Al- Qur'an
}

Nurul Farhana Yahaya \& Mohd Shukri Hanapi

To Link this Article: http://dx.doi.org/10.6007/IJARBSS/v10-i4/7161

DOI:10.6007/IJARBSS/v10-i4/7161

Received: 06 February 2020, Revised: 07 March 2020, Accepted: 12 March 2020

Published Online: 17 April 2020

In-Text Citation: (Yahaya \& Hanapi, 2020)

To Cite this Article: Yahaya, N. F., \& Hanapi, M. S. (2020). Humankind as Actors of Development According to The Al-Qur'an. International Journal of Academic Research in Business and Social Science, 10(4), 627-634.

Copyright: (C) 2020 The Author(s)

Published by Human Resource Management Academic Research Society (www.hrmars.com)

This article is published under the Creative Commons Attribution (CC BY 4.0) license. Anyone may reproduce, distribute, translate and create derivative works of this article (for both commercial and non-commercial purposes), subject to full attribution to the original publication and authors. The full terms of this license may be seen

at: http://creativecommons.org/licences/by/4.0/legalcode

Vol. 10, No. 4, 2020, Pg. 627 - 634

http://hrmars.com/index.php/pages/detail/IJARBSS

JOURNAL HOMEPAGE

Full Terms \& Conditions of access and use can be found at http://hrmars.com/index.php/pages/detail/publication-ethics 


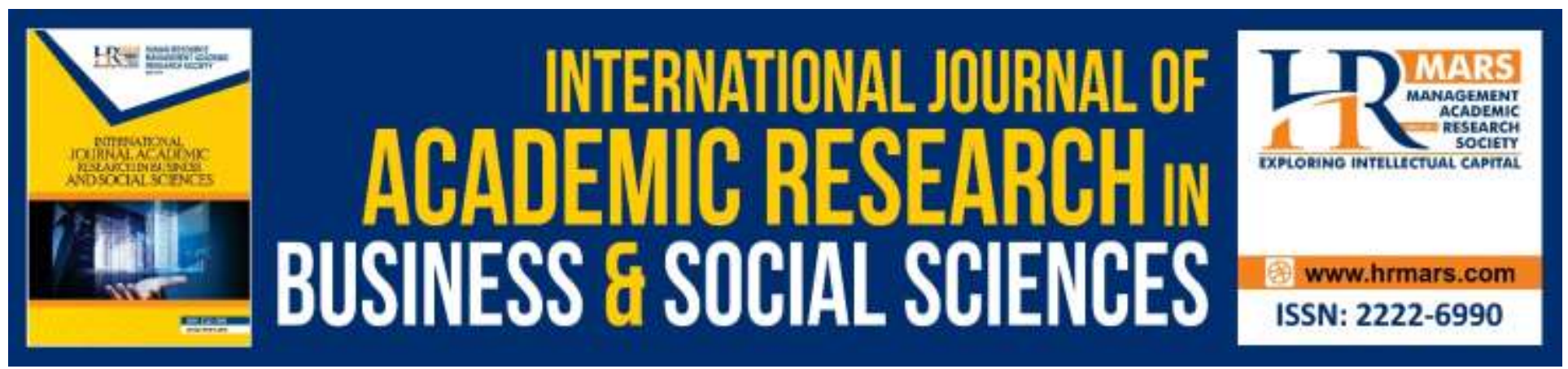

\title{
Humankind as Actors of Development According to The Al-Qur'an
}

\author{
Nurul Farhana Yahaya \& Mohd Shukri Hanapi \\ Centre for Islamic Development Management Sudies (ISDEV), University Sains Malaysia, 11800 \\ Minden, Penang, Malaysia.
}

\begin{abstract}
Each development process surely has its actors (development actors). In Islamic-based development theory and conventional development theory, humankind plays the role of a development actor. However, the role of humans as development actors in conventional development theory differs. So, what is the function of humans as development actors in conventional development theory? Is it consistent with the al-Qur'an? To answer both these questions, this working paper has two objectives, which is to identify the role of humans as development actors in conventional development theory and determine the function of humans as development actors based on the alQur'an. A library research on conventional development theory using the al-mawdhu'iy interpretation analysis method found that the humanistic role was solely confined to the physical and capability aspects, without considering the spiritual aspect. Therefore, the humanistic role in conventional development theory only considers the physical nature of humans or the pseudohuman perspective, which makes them "incomplete humans", as it only refers to their physical strength as well as productive and cognitive capabilities. This clearly contradicts the function of humans according to the al-Qur'an, which is to be the subject and khalifah of Allah SWT.
\end{abstract}

Keywords: Humans, Development Actors, Al-Qur'an, Al-Mawdhu'iy, Khalifah.

\section{Introduction and Objectives}

Each aspect of development cannot be implemented without development actors. In Islamic-based development theory (PBI), as in conventional development theory, the actor's role is played by humans. However, the function of humans as development actors in conventional development theory differs with that in Islamic-based development theory. According to conventional development, humans act as economic beings who solely produce and consume. The human function in PBI is to be the subject and khalifah of Allah SWT. The difference is due to the mould that forms these two development theories. PBI is moulded according to Islamic thinking, whereas, conventional development theory is moulded by conventional thinking. Since conventional development theory is moulded based on conventionality, hence, humans in this theory are only seen solely from their capability and physical aspects without considering the spiritual aspect. Thus, humans in conventional 
INTERNATIONAL JOURNAL OF ACADEMIC RESEARCH IN BUSINESS AND SOCIAL SCIENCES

Vol. 10, No. 4, April, 2020, E-ISSN: 2222-6990 @ 2020 HRMARS

development theory are often referred to their physical aspects or as "pseudo-humans", which refers to an "incomplete human". This is proven through the functional aspect of production in conventional development theory, whereby $P=f(T, M, B, K \ldots . n$ ) ( $P$ here stands for production, $M$ is capital, $B$ is labour, $\mathrm{K}$ is entrepreneurship and $\mathrm{n}$ is other factors of production). In terms of the production function, the factors of production related to humans are labour and entrepreneurship, which actually refer to aspects such as physical strength, production capability and the cognitive faculty. All these aspects do not take into consideration the spiritual element, such as faith (iman) and piousness (taqwa) as well as the main function of humans, which is to the subject and khalifah of Allah SWT (Salleh, 2003a:31).

In relation to this issue, this working paper had two main objectives, which is to identify the function of humans as actors of development in conventional development theory and then to analyse this function based on the al-Qur'an. Generally, the discussion in this paper is divided into three main parts. The first part discusses the function of humans as actors of development in conventional development theory, the second part discusses the function of humans as actors of development based on Islam and the third analyses the function of humans as actors of development based on the al-Qur'an.

\section{Methodology}

This is a qualitative study that examined primary and secondary sources. Secondary sources comprised previous studies and literary works, such as theses, journals, websites and writings related to the concept of development actors, conventional development theory and PBI. Besides that, this working paper also relied on the main referral sources of Islam, such as the al-Qur'an, Hadith and relevant literary works including interpretation (tafsir) scriptures. It was analysed using the almawdhu'iy interpretation method, which examined the human theme in the al-Quran by gathering verses of the al-Qur'an related to a theme or a surah or various surah in the al-Qur'an (Muslim, 1997:16). Similar themes were gathered and then analysed using the latest interpretation scriptures. This method was chosen because studies related to the al-Quran are best analysed by the almawdhu'iy interpretation method.

\section{Operational Definition}

This working paper discusses operational definitions related to development actors. According to Salleh (2003:15), humans as development actors have three important relationships in their lives. First is the relationship with Allah SWT, who is the Creator and humans as HIS subjects, second is the inter-human relationship in the context of humans being the khalifah of Allah SWT and third is the relationship between humans and nature. As a development actor, each human action is considered an ibadah because humans carry it out with full responsibility or takhlifan from Allah SWT in order to create a harmonious place on earth.

\section{Literature Review}

Generally, there are two main aspects in literature review, which are explained below. 
INTERNATIONAL JOURNAL OF ACADEMIC RESEARCH IN BUSINESS AND SOCIAL SCIENCES Vol. 10, No. 4, April, 2020, E-ISSN: 2222-6990 @ 2020 HRMARS

\section{Humans as Development Actors in Conventional Development Theory}

In conventional development, religion is a tool for development and not development as a tool for religion. Todaro (1977:62) was of the view that development must be seen as a multidimensional process that includes various types of changes, such as changes in social structure, society's attitudes, national institutions, eradication of poverty, reducing the gap between the rich and poor and pursuing economic growth. In brief, development must reflect overall changes or a comprehensive accommodation of the social system, without excluding various basic needs (food, housing, health, peace). It should also consider the wishes of individuals or social groups, such as possessing greater wealth, defending one's dignity and freedom that leads to a better life, either materialistic or spiritual.

The views of Todaro (1977) are consistent with that of Lewis (1982:10), who said that economic growth depends on the attitude and human thinking towards work, wealth, frugality etc. Nevertheless, it is said that it will be easier for economic growth to succeed if religion accommodates and all types of progressive changes explored by the contemporary system (secular system) as halal. Lewis (1982) emphasised that in order to experience progress, religion should not restrict any method or product. Although Todaro (1977) and Lewis (1982) had touched on the spiritual and religious elements, it is presumed to be part of development. For example, Todaro (1977) was inclined to see the success of physical and material developments in improving the spiritual life, and not the spiritual aspect improving the physical and material developments. Meanwhile, Lewis (1982) had put religion at a very low level because he wanted religion to support the secular system in order for development to experience continued progress without any hindrance. In this case, religion is seen as a tool for development and not vice versa. Hence, this clearly shows that conventional development theory believes that humans can and should manage their economic development without considering the religious perspective.

It is clear here that the function of humans in conventional development theory is not more than a piece of merchandise or tool (Salamon, 1989:75). Hence, the actor of development in conventional development theory is meant only to carry out a stereotype and secularist function, such as consuming, growing, learning, working, reproducing and dying. They are also presumed to be humans who produce and consume as well as their strength is measured in terms of their physical, cognitive and skills qualities as well as all matters that physically exist.

\section{Humans as Actors of Islamic-based Development (PBI)}

Humans in a development entity are a group that is given the responsibility, blessed with a thinking mind and instilled with nobility by Allah SWT (Muhsin Abdul al-Hamid, 1998:33). In this case, humans are given a mind, soul and physique that can administer and develop nature. Therefore, humans are invited to further understand knowledge as a preparation for implementing development. This is also because Allah SWT has testified that humans are the most noble (asyraf al-makhluqat) and best (ahsan al-khaliqin) subjects (Borham, 2007:2).

Humans, as PBI actors, are designed with a function, which is to be the subject and khalifah of Allah SWT. Humans in PBI have an ultimate aim regarding development and a clear pathway in life, which 
INTERNATIONAL JOURNAL OF ACADEMIC RESEARCH IN BUSINESS AND SOCIAL SCIENCES Vol. 10, No. 4, April, 2020, E-ISSN: 2222-6990 @ 2020 HRMARS

is to achieve the blessings of Allah SWT and obtain ultimate success (al-falah) (Ghazali, 1990; Ahmad, 2006). Whereas, in the context of managing the available natural resources, humans take great care to safeguard the trust given and manage the resources with full dedication (Kasim Mansur, 2008). Next, the main character role, which is the core feature in humans as actors in the development process, is the staunch belief in tauhid when planning a development initiative.

\section{Findings and Discussions}

Based on earlier discussions, humans were found to be actors in the development process, either conventional or Islam-based development processes. However, humans carried out different functions in these two processes. The details of the findings are as follows.

\section{Analysis of the Function of Humans as Development Actors Based on the al-Qur'an}

According to the al-Qur'an, humans are a composite entity consisting of physical, spiritual, cognitive and instinctual elements (Jar, 1986:17; Ahmad, 2014). Islam views the physical element as being haywaniyyah (animalistic) in nature, while the spiritual element as being natiqah (rational). The symbiosis between these aspects makes humans what they are as both combine with each other to lend meaning to life. Thus, if one is absent or the significance of one is neglected, then humans will no longer be humans (Ahmad, 2014).

Hence, humans, as a creation of Allah SWT, have a more specific function than that in conventional development, which is moulded according to conventional worldview (tasawur). According to Salleh (2003:23), production and consumption activities are only part of the tools required by humans to implement or maintain their specific function, which is a responsibility given to them as subjects and khalifah of Allah SWT on this earth. According to Qutb (1987:60), being a subject is a function that connects humans to Allah SWT ( habl min Allah), whereas, being a khalifah connects humans to humans (habl min al-nas).

Based on the status of being a subject and khalifah of Allah SWT, Salleh (2003:15) stated that humans, as actors in the Islamic-based development theory, differ in their function compared to being actors in conventional development theory. There are two main differences. First, actors in the Islamicbased development process have a philosophy and function that differs from conventional development. As subjects of Allah SWT, they get involved in development activities in order to totally devote themselves (ibadah) to Allah SWT. When performing the ibadah they always vindictive their subservience to Allah SWT. As a khalifah of Allah SWT, they interact with humans and nature with a feeling of responsibility and trust, while equipped with a good personality supported by ethical values that are suitable with their role as a khalifah of Allah SWT on this earth; second, Islamic-based actors of development are not bound by the economic aspects that are solely evaluated using productivity, production and consumerism measures, as indicated by conventional development actors. Conversely, as a subject of Allah SWT, Islamic-based development actors have a very strong relationship with Allah SWT (habl min Allah), besides being the khalifah of Allah SWT, while maintaining a relationship with other humans and natural resources (habl min al-nas). The reward for upholding both these relationships is not only found in this world, in a materialistic form, but it is also found in the afterword in the form of heaven. 
The combination of both these major functions in human creation shows that humans function as actors of development based on the tasawur al-Qur'an. According to Muhammad Syukri Salleh (2003), as an actor of development, humans must vindictive their status as a subject and khalifah on this earth. In the vertical relationship with Allah SWT ( $h a b l$ min Allah), humans are subjects of Allah SWT. In a horizontal relationship between humans and nature ( $h a b /$ min al-nas), humans play the role of a halifah. Therefore, actors of development are not only born to carry out a stereotype and secularist function, such as consume, grow, learn, work, raise a family, reproduce and die. It cannot be presumed that humans are only producers or consumers, whereby only the physical, cognitive and skills qualities as well as all other tangible elements are taken into consideration. All forms of production and consumerism activities pose as one of the human tools used to prove the submission to Allah SWT (stipulated) since humans are in the spiritual world (al-A'raf, 7:172 \& al-Hadid, 57:8). Moreover, it is also a tool to fulfil basic human needs in life. In whichever activity or action, the status of a subject and khalifah of Allah SWT is inseparable.

In relation to this, when implementing a development process, humans cannot become a subject of development because development is actually meant for humanity and not vice versa (Salleh, 2002:67 \& 2003:31). Thus, only now can actors of development truly produce development, which is included in the category of ibadah and accepted by Allah SWT.

\section{Conclusion}

Humans in conventional development theory are presumed to be economic entities whose function is only to produce and consume. In this case, what is considered is only the strength of the physical, cognitive, skill qualities and all matters that physically exist. Besides that, humans are also presumed to be the measure of all things as well as the owner and source of all rights. It is evident here that humans in conventional development theory are merely treated as a type of merchandise or tool. They are thought to be born only to carry out a stereotype and secularist function, such as to consume, grow, learn, work, have a family, reproduce and eventually die. The human function in conventional development theory clearly contradicts the human function according to tasawur alQuran, which is to be the subject and khalifah of Allah SWT. Humans' status as the subject and khalifah of Allah SWT instils in the Islamic-based development actor a type of philosophy and function that differs from the conventional development actor. As a subject and khalifah of Allah SWT, involvement in development activities is one way of totally submitting oneself to Allah SWT. In this case, humans in PBI defend their role as subjects of Allah SWT and the duty they perform as a khalifah.

\section{Corresponding Author}

Nurul Farhana Yahaya, Centre for Islamic Development Management Studies (ISDEV), University Sains Malaysia, 11800 Minden, Penang, Malaysia.

Email: nfarhanayahaya@gmail.com. 
INTERNATIONAL JOURNAL OF ACADEMIC RESEARCH IN BUSINESS AND SOCIAL SCIENCES

Vol. 10, No. 4, April, 2020, E-ISSN: 2222-6990 @ 2020 HRMARS

\section{References}

Ahmad, A. R. (2006). Pembangunan modal insan: apa dan kenapa perlu dalam konteks organisasi di Malaysia. Kuala Lumpur: Human Resources Academy.

Ahmad, S. (1990). "Fungsi dan Peranan Islam Dalam Pembangunan Ummah: Antara Harapan dan Kenyatan", dlm Muhammad Syukri Salleh (ed.), Konsep dan pelaksanaan pembangunan berteraskan Islam. Pulau Pinang: Universiti Sains Malaysia.

al-Hamid, M. A. (1998). Islam dan pembangunan sosial. Selangor: Thinker's Library Sdn. Bhd.

Al-Jauziy, I. Q. (1981). al-Amthal Fi al-Qur'an al-Karim. Lubnan: Dar al-Ma'rifah.

Al-Khalidiy, S. (2001). Al-Tafsir al-Mawdhu'iy Bayn al-Nazariyyat wa al-Tatbiq Dirasat Nazariyyat wa Tatbiqiyyat Murafaqat bi Namazij wa Lata'if al-Tafsir. 'Amman, Jordan: Dar al-Nafa' is

Al-Qattan, M. K. (1973). Studi ilmu-ilmu al-Qur'an, terj. Mudzakir. Jakarta: Pustaka Litera.

al-Zamakhshari, M. (n.d.), Tafsir al-Kashshaf 'an Haqaiq Ghawamid al-Tanzil. Bayrut: Dar al-Kitab alArabi

Ali, M. (2013). Fungsi perumpamaan dalam al-Qur'an. Jurnal Tarbawiya. Vol 10 No.2,2013.

Ali, S. H. (1976). Apa Erti Pembangunan. Kuala Lumpur: Dewan Bahasa dan Pustaka.

Anas, W. N. I. W. N., Khairuldin, W. M. K. F. W. K., Mohd, H., \& Ali, A. K. (2020). Rehabilitation of

Transsexual Based on Preaching Psychology in Islam. International Journal of Disaster

Recovery and Business Continuity. Vol. 11 (1), pp. 682-687

Babilli, M. M. (1988). Ekonomi Dari Kacamata Islam. Terengganu: Yayasan Islam Terengganu.

Bakar, M. S. A. (1995). Metodologi Penyelidikan Untuk Ekonomi Dan Bidang Berkaitan. Bangi: Universiti Kebangsaan Malaysia.

Borham, A. J. (2008). Asas pembangunan modal insan. Pahang: Penerbit Universiti Malaysia Pahang. Chapra, U. (2001). Masa Depan IImu Ekonomi Sebuah Tinjauan Islam. Jakarta: Gema Insani Press.

Chapra, U. (2001). Masa depan ilmu ekonomi sebuah tinjauan Islam. Jakarta: Gema Insani Press.

Ghazali, A. (1990). Development an Islamic Perspective. Selangor: Pelanduk Publications.

Gilarso, T. (2003). Pengantar Ekonomi Mikro. Yogyakarta: Penerbit Kanisius.

Hamat, M. F. (2012). Tinjauan Kepentingan Pembangunan Modal Insan di Malaysia. Jurnal alTamadun. Bil. 7(1) 2012, 75-89. Kuala Lumpur: Akademi Pengajian Islam, Universiti Malaya.

Hanapi, M. S. (2012). Tasawur Pembangunan Dalam al-Qur'an: Kajian Tafsir al-Mawdhu'iy. Tesis Sarjana Pengurusan Pembangunan Islam yang diserahkan kepada Faku Iti Sains Kemasyarakatan, Universiti Sains Malaysia. Tidak diterbitkan.

Hasan, S. K., \& Ahmad, S. (2005). Ekonomi Islam. Kuala Lumpur: Dewan Bahasa dan Pustaka.

Hassan, M. K. (1990). "Pembangunan Yang Berteraskan Islam”, dlm Muhammad Syukri Salleh (ed.), Konsep dan pelaksanaan pembangunan berteraskan Islam. Pulau Pinang: Universiti Sains Malaysia.

Ibn Manzur, Abu al-Fadl Jamal al-Din Muhammad. (1990). Lisan al-'Arab. Beirut :Dar alSadir.

IbnManzur, M. (1999). Lisan al-'Arab. Beirut: Dar al-Ihya' al-Turath al-Arabiy.

Ismail, R. (1996). Modal Manusia dan Perolehan Buruh. Kuala Lumpur: Dewan Bahasa dan Pustaka.

Jar, M. M. (1986). "Konsep Manusia dari Perspektif Barat dan Islam”, dlm Wan Hashim dan Mahayudin Yahaya (Ed), Sains Sosial Dari Perspektif Islam. Bangi: Universiti Keb angsaan Malaysia. 
INTERNATIONAL JOURNAL OF ACADEMIC RESEARCH IN BUSINESS AND SOCIAL SCIENCES

Vol. 10, No. 4, April, 2020, E-ISSN: 2222-6990 @ 2020 HRMARS

Khairuldin, W. M. K. F. W., Anas, W. N. I. W. N., Embong, A. H., Hassan, S. A., Hanapi, M. S., \& Ismail, D. (2019). Ethics of mufti in the declaration of fatwa according to Islam. Journal of Legal, Ethical and Regulatory Issues, 22(5), pp. 1-6.

Khairuldin, W. M. K. F. W., Embong, A. H., Anas, W. N. I. W. N., Mohd, H., \& Ismail, D. (2018). The Application of Technology in the Dissemination of Fatwas: A Study on Religious Institutions in Malaysia, International Journal of Civil Engineering and Technology, 9(7), 2018, pp. 15901596.

Khairuldin, W. M. K. F. W., Embong, A. H., Hassan, S. A., Yasin, M. F. M., \& Anas, W. N. I. W. N. (2019). Strategic management in fatwa-making process. Academy of Strategic Management Journal, 18(4), pp. 1-6.

Madhkur, I. (1985), al-Mu'jam al-Wasit. Kaherah: t.t.

Mansur, K. (2009). Pembentukan Modal Insan Cemerlang: Pendekatan Ekonomi Islam. Sabah: Universiti Malaysia Sabah.

Muhammad, A. (2008). Perumpamaan al-Qur'an. Johor: Universiti Teknologi Malaysia.

Nain, A. S. M., \& Yusoff, R. M. (2003). Konsep, teori, dimensi dan isu pembangunan. Johor: Universiti Teknologi Malaysia.

Said, A. M. (2007). "Pembangunan Modal Insan: Konsep, Perkembangan, Cabaran dan Implikasi”, dlm Khalidah Salekan dan Ahmad Mohamad Said (Ed), Pembangunan Insan: Aspirasi dan Realiti. Selangor: Kolej Dar al-Hikmah.

Salleh, M. S. (1990). "Pembangunan Untuk Manusia Atau Manusia Untuk Pembangunan: Analisis Tentang Manusia dalam Pembangunan Berteraskan Islam", dlm Muhammad Syukri Salleh (ed.), Konsep dan pelaksanaan pembangunan berteraskan Islam. Pulau Pinang: Universiti Sains Malaysia.

Salleh, M. S. (2003). 7 Prinsip Pembangunan Berteraskan Islam. Kuala Lumpur: Zebra Editions Sdn. Bhd.

Salleh, M. S. (2013). Philosophical Foundations of Islamic Development: Khurshid Ahmad's Conception Revisited. Jurnal International Journal of Education and Research 7.

Soed, S., \& Zakaria, M. N. (2005). Asas-asas Ekonomi. Pahang: PTS Profesional

Todaro, M.P. (1978). Economic Development in the Third World: An Introduction to the problems and policies in a global perspective. London and New York: Longman.

Willis, K. (2005). Theories and Practices of Development. London: Routledge Taylor and Francis Group. Yasin, M. F. B. M., Embong, A. H., Khairuldin, W. M. K. F. W., Sulaiman, R., Abdullah, A., Said, S., Mutalib, N. A. (2018). Contributions of technology towards development of Qur'anic tajweed knowledge. International Journal of Civil Engineering and Technology, 9(6), pp. 1340-1352.

Yusof, A. A. (2012). Pembangunan Holistik Dari Perspektif Islam. Kuala Lumpur: Dewan Bahasa dan Pustaka.

Yussof, I., \& Osman, Z. (2008). "Pembangunan Modal Insan di Malaysia: Perspektif Ekonomi”, dlm Yahaya Ibrahim (eds), Pembangunan Modal Insan Isu dan Cabaran. Bangi: Universiti Kebangsaan Malaysia. 